\title{
Inhibition Studies of Naturally Occurring Terpene based Compounds with Cyclin-Dependent Kinase 2 Enzyme
}

Sunil H Ganatra* and Amita S Suchak

Department of Chemistry, Institute of Science, Civil Lines, Nagpur-440001, India

\begin{abstract}
The knowledge of the molecular basis of carcinogenesis has helped to discover new, less toxic chemotherapy agents. At present, considerable attention has been focused on identifying the molecular level interactions of naturally occurring Terpene based substances, capable of inhibiting target enzymes. CDKs enzymes are known as cell regulators in eukaryotic cell cycle. In finding new anti-cancer agents, CDKs are used as target enzymes, particular among them are CDK2 enzymes.

Computer based Chem-office and Autodock molecular modeling tools used to understand the ways with which Terpene based natural products interacts with Cyclin-dependent kinase 2 (CDK2). Using in-silico techniques, the binding energy between ligands and receptor enzyme are calculated in the form of $\Delta \mathrm{G}$ in $\mathrm{Kcal}_{\text {.mol }}{ }^{-1}$. The reported binding energies for series of molecules are ranging from -7.96 to $-16.62 \mathrm{Kcal}^{\mathrm{mol}}{ }^{-1}$. The negative docking energies and a few hydrogen bonds between ligand and receptor enzyme support the affinity of Terpene based compounds with selected enzyme. Number of hydroxyl groups present in ligand enhances the interaction strength and stability of complex. The finding confirms the affinity of Terpene based natural products as CDK2 inhibitor.
\end{abstract}

Keywords: Anti-cancer agent; Natural product; Terpene; Drug discovery; CDK protein; Cancer; In-silico; Molecular modeling; Docking

\section{Introduction}

Natural products played most vital role in human disease treatment $[1,2]$. It is reported that $60 \%$ of drugs used for treating cancer are born from natural products [3]. Presently, more than 23000 known natural products, Terpene based compounds are the largest class of natural products [4,5]. Among this group, many interesting compounds show biological activities and used as a medicine for treating various diseases including cancer [5,6]. For example, Paclitaxel (Taxol $\left.{ }^{\circledR}\right)$ is used in treating breast cancer. These compounds are also used in varieties of diseases including cancer chemopreventive effects, anti-microbial, anti-fungal, anti-viral, anti-hyperglycemic, anti-inflammatory, and anti-parasitic activities [7-9].

The drug discovery process activates from the selection of target enzyme. The drug molecule interacts with target enzyme and inhibits it. The successful inhibition of enzyme with small drug molecule stops the normal functioning of enzyme. In major cases of cancer treatment the cell regulator enzymes are target enzymes [8]. A family of conserved serine/threonine kinase known as cyclin-dependent kinases (CDKs) drives orderly cell cycle progression in eukaryotic cell. The cyclin-dependent protein kinases [10] are regulators of the timing and coordination of eukaryotic cell cycle events [11]. Prior studies have suggested that CDK2 regulates S-phase entry and progression, and frequently shows increased activity in a wide spectrum of human tumors [12].

CDKs are inactive as monomers and their activation requires binding to cyclins with phosphorylation by CDK-activating kinase on a specific threonine residue. The cyclin belongs to diverse family of proteins and their level oscillates during cell cycle $[13,14]$. It is difficult to design the inhibitor specific to a particular CDKs due to the structural homology among number of CDKs (CDK2, CDK4 etc.) [15]. CDK2 activity is necessary for normal mammalian cell cycle progression and it is suggested that CDK2 might be a useful therapeutic target for treating cancer [12].
The crystal structure of CDK2 is available and one among many available structures is having $\mathrm{PDB}$ reference $2 \mathrm{BHH}$. This crystal structure contains natural inhibitor (2e,3s)-3-Hydroxy-5'-[(4Hydroxypiperidin-1-Yl) Sulfonyl]-3-Methyl-1,3-Dihydro-2,3'- Biindol2'(1'h)-One.

Majority of plant origin compounds are tested against CDKs and found active but still the interactions involved between these compounds and CDKs are not studied in detail.

Availabilities of various computer processing based drug discovery tools help in providing the insight of interactions between small molecules and target enzymes. The importance of these tools is due to their ability to show possible interactions between ligand and receptor enzyme at atomic level. They also calculate the probable binding energy between them and explore the numerous possibilities of ligand conformations inside enzyme active sites. These tools provide the binding energy $\left(\Delta \mathbf{G}_{\text {bind }}\right)$ in $\mathrm{kcal}^{\mathrm{mol}} \mathrm{l}^{-1}$ between ligand and receptor enzyme (or of complex formed). This technique is used for screening the library of molecules showing better interactions for further drug discovery processes. The techniques save time and cost accounted for drug discovery process.

Terpene based natural products can be made more effective as a drug if their interactions with enzyme at molecular level are known. This is possible by using computer based molecular modeling techniques. There are numerous computer based drug discovery programs available in market which help in mimicking the chemical compound

*Corresponding author: Sunil H Ganatra, Department of Chemistry, Institute of Science, Civil Lines, Nagpur-440001, India, E-mail: sunilganatra@gmail.com

Received April 21, 2012; Accepted July 07, 2012; Published July 10, 2012

Citation: Ganatra SH, Suchak AS (2012) Inhibition Studies of Naturally Occurring Terpene based Compounds with Cyclin-Dependent Kinase 2 Enzyme. J Comput Sci Syst Biol 5: 068-073. doi:10.4172/jcsb.1000092

Copyright: (c) 2012 Ganatra SH, et al. This is an open-access article distributed under the terms of the Creative Commons Attribution License,which permits unrestricted use, distribution, and reproduction in any medium, provided the original author and source are credited. 
Citation: Ganatra SH, Suchak AS (2012) Inhibition Studies of Naturally Occurring Terpene based Compounds with Cyclin-Dependent Kinase 2 Enzyme. J Comput Sci Syst Biol 5: 068-073. doi:10.4172/jcsb.1000092

interactions with enzyme and provides valuable information related to types of interactions, possibilities of bonding and conformations. The most prominent technique is docking of small molecule (ligand) with target enzyme. Gold, Autodock, Dock, ArgusLab etc. are a few computer based docking programs presently available in market. Binding energy in $\mathrm{kcal}_{\mathrm{mol}}{ }^{-1}$ is the major parameter investigated using these programs along with steric, hydrophobic and electrostatic interactions. It also provides the list of possible hydrogen bonding between ligand and enzyme. The state of art graphics shows the ligand-enzyme complex from various angles.

In present study, twenty five naturally occurring Terpenes are selected and tested for their inhibition possibilities with CDK2 (PDB reference $2 \mathrm{BHH}$ ) enzyme using molecular docking techniques. The aim is to investigate the possible binding energies, various interaction poses, and possible hydrogen bonding and hence understanding the effectiveness of these molecules as a CDKs inhibitor, specifically CDK2 inhibitor.

\section{Materials and Methods}

\section{Design of small molecules (Ligand)}

To study inhibition of enzyme with designed small molecules (called as ligand), twenty five Terpene based known natural products are selected as listed in Table 1.

\section{Ligand preparation}

The structures of 25 Terpene based plant-derived compounds

\begin{tabular}{|c|c|c|}
\hline Molecule No. & Phytochemical Name & Molecular Formula \\
\hline 1 & Abietane & $\mathrm{C}_{20} \mathrm{H}_{36}$ \\
\hline 2 & Abscisic acid & $\mathrm{C}_{15} \mathrm{H}_{20} \mathrm{O}_{4}$ \\
\hline 3 & Aconitine & $\mathrm{C}_{34} \mathrm{H}_{47} \mathrm{NO}_{11}$ \\
\hline 4 & Aphidicolin & $\mathrm{C}_{22} \mathrm{H}_{36} \mathrm{O}_{5}$ \\
\hline 5 & Arjunolic acid & $\mathrm{C}_{30} \mathrm{H}_{48} \mathrm{O}_{5}$ \\
\hline 6 & Betulin & $\mathrm{C}_{30} \mathrm{H}_{50} \mathrm{O}_{2}$ \\
\hline 7 & Cannabinol & $\mathrm{C}_{21} \mathrm{H}_{26} \mathrm{O}_{2}$ \\
\hline 8 & Gingerol & $\mathrm{C}_{17} \mathrm{H}_{26} \mathrm{O}_{4}$ \\
\hline 9 & Ginsenoide & $\mathrm{C}_{30} \mathrm{H}_{52} \mathrm{O}_{2}$ \\
\hline 10 & Glaucarubin & $\mathrm{C}_{25} \mathrm{H}_{36} \mathrm{O}_{10}$ \\
\hline 11 & Kaurane & $\mathrm{C}_{20} \mathrm{H}_{34}$ \\
\hline 12 & Labdane & $\mathrm{C}_{20} \mathrm{H}_{38}$ \\
\hline 13 & Limonene & $\mathrm{C}_{10} \mathrm{H}_{16}$ \\
\hline 14 & Lupeol & $\mathrm{C}_{31} \mathrm{H}_{52} \mathrm{O}$ \\
\hline 15 & Lutein & $\mathrm{C}_{40} \mathrm{H}_{56} \mathrm{O}_{2}$ \\
\hline 16 & Lycopene & $\mathrm{C}_{40} \mathrm{H}_{56}$ \\
\hline 17 & Maslinic acid & $\mathrm{C}_{30} \mathrm{H}_{48} \mathrm{O}_{4}$ \\
\hline 18 & Neurosporene & $\mathrm{C}_{40} \mathrm{H}_{58}$ \\
\hline 19 & Oleanolic acid & $\mathrm{C}_{30} \mathrm{H}_{48} \mathrm{O}_{3}$ \\
\hline 20 & Phytofluene & $\mathrm{C}_{40} \mathrm{H}_{62}$ \\
\hline 21 & Sapogenin & $\mathrm{C}_{27} \mathrm{H}_{42} \mathrm{O}_{4}$ \\
\hline 22 & Taraxosterol & $\mathrm{C}_{30} \mathrm{H}_{50} \mathrm{O}$ \\
\hline 23 & Tetrahydrocannabinol & $\mathrm{C}_{21} \mathrm{H}_{30} \mathrm{O}_{2}$ \\
\hline 24 & Ursolic acid & $\mathrm{C}_{30} \mathrm{H}_{48} \mathrm{O}_{3}$ \\
\hline 25 & Zeaxanthin & $\mathrm{C}_{40} \mathrm{H}_{56} \mathrm{O}_{2}$ \\
\hline
\end{tabular}

Table 1: List of Terpene-Based Phytochemicals.

Non-genetical docking parameters
Grid Resolution $=0.4$
Number Of Steps $=50$
Genetical docking parameters
The population size $=100$
Maximum Generation $=5000$
Elitism Number $=5$
Crossover Rate $=0.8$
Mutation Rate $=0.2$
Local Search Rate $=0.06$
Local Search Maximum Iteration $=20$
Converged when RMSD Population Fitness $<1$ kcal.mole ${ }^{-1}$
Grid Dimensions $=67 \times 77 \times 61$
Total Number Of Grid Points $=314699$
Grid Resolution $=0.4$

Table 2: Selected Parameters for Non-Geneticaland Genetical Docking.

are designed in-silico using Chem-office software [16]. Initially 2-D structures were designed. The 2-D compounds converted to 3-D using Molecular Mechanics (MM2) method with the help of Chem-office software [16]. The designed molecules are checked for its conformation by ascertaining achievement of global minima. The list of compounds designed along with molecular formula is listed in Table 1.

\section{Receptor enzyme}

Electronic structure of CDK2 is selected as a target protein having $\mathrm{PDB}$ reference $2 \mathrm{BHH}$. The protein file procured from online data base having (2E,3S)-3-HYDROXY-5'-[(4-HYDROXYPIPERIDIN-1-YL) SULFONYL]-3-METHYL-1,3-DIHYDRO-2,3'-BIINDOL-2'(1'H)-ONE as a natural inhibitor [17]. The selected enzyme structure was prepared in such a way that it has no ambiguities in the form of missing atoms or amino acids. All the heteroatoms (i.e. non-receptor atoms such as water, ions, etc.) were removed followed by assigning Kollmann charges. The Solvation parameters were added to the final macromolecule structure using the Addsol utility of AutoDock [18].

The place of natural inhibitor in enzyme is treated as active site of selected enzyme and used as it is without any further processing.

\section{Docking}

Autodock 4.0 [18] is used for docking process. Initially protein grid was designed using grid design tool of Autodock. Dockings were performed using both genetic (GA) and non-genetic (Non-GA) algorithm techniques. The genetic algorithm (GA) is the newly adopted conformational search techniques and searches the best possible conformations of ligand inside the active site of enzyme. For each conformational position, it also reports the possible binding energy in the form of $\Delta \mathrm{G}$ in $\mathrm{kcal}_{\text {. }} \mathrm{mol}^{-1}$. The selected parameters and settings, which were used for docking, are listed in Table 2.

The docking algorithm makes use of force field equations and parameters to calculate the binding energy between ligand and enzyme [19-25]. The binding free energy is the total of van der Waals interactions, H-bond interactions, electrostatic interactions and the internal static energy of the ligand as shown in Equation 1 [26-33].

$$
\Delta \mathrm{G}_{\text {bind }}=\Delta \mathrm{G}_{\mathrm{vdw}}+\Delta \mathrm{G}_{\text {hydrophobic }}+\Delta \mathrm{G}_{\mathrm{H}-\text { bond }}+\Delta \mathrm{G}_{\mathrm{H}-\text { bond(chg) }}+\Delta \mathrm{G}_{\text {deformation }}+
$$

The obtained results of binding energy for Non-GA and GA Dockings for each set of experiments are listed in Table 3. The negative values of docking energies favour the interaction among ligand and enzyme. Though there are chances of non-favourable interactions, the non-favourable results are marked as ' '. 
Citation: Ganatra SH, Suchak AS (2012) Inhibition Studies of Naturally Occurring Terpene based Compounds with Cyclin-Dependent Kinase 2 Enzyme. J Comput Sci Syst Biol 5: 068-073. doi:10.4172/jcsb.1000092

\section{Results}

There are number of CDK2 electronic structures available in protein databank [17]. The selection of $2 \mathrm{BHH}$ is due to presence of natural inhibitor located in one of the main active sties. This structure is also error free and complete one.

Table 3 lists obtained binding energies for all docked molecules. The reported values of docking energies are between -8.89 to -17.20 kcal.mol ${ }^{-1}$ and -8.58 to $-16.62 \mathrm{kcal}^{\mathrm{mol}}{ }^{-1}$ for Non-GA and GA docking respectively. Both types of docking give nearly same results. The binding energy is not reported for a few compounds in non-GA docking. Hence for further analysis and comparisons only GA docking were used. All compounds report negative binding energy and hence possibilities of stable complex formation. The stability is also enhancing in few compounds due to the formation of hydrogen bonding (HB).

\section{Hydrogen bonding analysis}

The strength of the $\mathrm{HB}$ is evaluated from the bond distance. Autodock provides the possibilities of HBs between ligand and protein. Though software reports nearly all possibilities of $\mathrm{HBs}$, only those bonds having length less than $2.5 \AA$ are counted and others are discarded. However, it is possible to have less binding energy and higher HBs; this may be due to lack of other types of interactions.

Depending on the binding energy of GA docking and HB, out

\begin{tabular}{|c|c|c|c|c|}
\hline \multirow{2}{*}{$\begin{array}{l}\text { Molecule } \\
\text { Number. }\end{array}$} & \multirow{2}{*}{$\begin{array}{l}\text { Phytochemical } \\
\text { Name }\end{array}$} & \multirow{2}{*}{$\begin{array}{l}\text { Molecular } \\
\text { Formula }\end{array}$} & \multicolumn{2}{|c|}{ Docking Energy $(\Delta G)$ in kcal mol-1 } \\
\hline & & & Non-GA Docking & GA Docking \\
\hline 1 & Abietane & $\mathrm{C}_{21} \mathrm{H}_{38}$ & -12.90 & -12.42 \\
\hline 2 & Abscisic acid & $\mathrm{C}_{15} \mathrm{H}_{20} \mathrm{O}_{4}$ & -10.70 & -9.55 \\
\hline 3 & Aconitine & $\mathrm{C}_{34} \mathrm{H}_{47} \mathrm{NO}_{11}$ & * & -8.58 \\
\hline 4 & Aphidicolin & $\mathrm{C}_{22} \mathrm{H}_{36} \mathrm{O}_{5}$ & -10.27 & -11.10 \\
\hline 5 & Arjunolic acid & $\mathrm{C}_{30} \mathrm{H}_{48} \mathrm{O}_{5}$ & -11.19 & -12.09 \\
\hline 6 & Betulin & $\mathrm{C}_{30} \mathrm{H}_{50} \mathrm{O}_{2}$ & -12.27 & -12.77 \\
\hline 7 & Cannabinol & $\mathrm{C}_{21} \mathrm{H}_{26} \mathrm{O}_{2}$ & -11.91 & -13.71 \\
\hline 8 & Gingerol & $\mathrm{C}_{17} \mathrm{H}_{26} \mathrm{O}_{4}$ & -10.97 & -8.65 \\
\hline 9 & Ginsenoside & $\mathrm{C}_{30} \mathrm{H}_{52} \mathrm{O}_{2}$ & -13.84 & -12.10 \\
\hline 10 & Glaucarubin & $\mathrm{C}_{25} \mathrm{H}_{36} \mathrm{O}_{10}$ & * & -9.24 \\
\hline 11 & Kaurane & $\mathrm{C}_{20} \mathrm{H}_{34}$ & -12.35 & -13.02 \\
\hline 12 & Labdane & $\mathrm{C}_{20} \mathrm{H}_{38}$ & -12.30 & -11.67 \\
\hline 13 & Limonene & $\mathrm{C}_{10} \mathrm{H}_{16}$ & -10.65 & -9.85 \\
\hline 14 & Lupeol & $\mathrm{C}_{31} \mathrm{H}_{52} \mathrm{O}$ & -13.49 & -13.75 \\
\hline 15 & Lutein & $\mathrm{C}_{40} \mathrm{H}_{56} \mathrm{O}_{2}$ & -15.72 & -14.78 \\
\hline 16 & Lycopene & $\mathrm{C}_{40} \mathrm{H}_{56}$ & * & -7.96 \\
\hline 17 & Maslinic acid & $\mathrm{C}_{30} \mathrm{H}_{48} \mathrm{O}_{4}$ & -9.98 & -11.32 \\
\hline 18 & Neurosporene & $\mathrm{C}_{40} \mathrm{H}_{58}$ & * & -16.05 \\
\hline 19 & Oleanolic acid & $\mathrm{C}_{30} \mathrm{H}_{48} \mathrm{O}_{3}$ & -11.02 & -14.65 \\
\hline 20 & Phytofluene & $\mathrm{C}_{40} \mathrm{H}_{62}$ & * & -10.61 \\
\hline 21 & Sapogenin & $\mathrm{C}_{30} \mathrm{H}_{50} \mathrm{O}_{3}$ & -8.89 & -13.02 \\
\hline 22 & Taraxosterol & $\mathrm{C}_{30} \mathrm{H}_{50} \mathrm{O}$ & -13.09 & -12.60 \\
\hline 23 & Tetrahydrocannabinol & $\mathrm{C}_{21} \mathrm{H}_{30} \mathrm{O}_{2}$ & -10.69 & -12.75 \\
\hline 24 & Ursolic acid & $\mathrm{C}_{30} \mathrm{H}_{48} \mathrm{O}_{3}$ & -12.89 & -12.74 \\
\hline 25 & Zeaxanthin & $\mathrm{C}_{40} \mathrm{H}_{56} \mathrm{O}_{2}$ & -17.20 & -16.62 \\
\hline
\end{tabular}

Table 3: List of Observed Binding Energy of Terpene-Based Molecules with CDK2 Enzyme (PDB Ref. 2BHH).

\begin{tabular}{|l|l|l|l|l|l|}
\hline $\begin{array}{l}\text { Molecule } \\
\text { No. }\end{array}$ & $\begin{array}{l}\text { Molecular } \\
\text { Formula }\end{array}$ & $\begin{array}{l}\text { Binding Energy } \\
\mathrm{K} \text { in } \\
\text { Kcal.Mol-1 }\end{array}$ & $\begin{array}{l}\text { Total } \\
\text { Hydrogen } \\
\text { Bonding }\end{array}$ & $\begin{array}{l}\text { Amino Acids } \\
\text { Involved } \\
\text { in Hydrogen } \\
\text { Bonding }\end{array}$ & $\begin{array}{l}\text { Hydrogen } \\
\text { Bonding } \\
\text { Distance } \\
\text { in } \AA\end{array}$ \\
\hline 7 & $\mathrm{C}_{21} \mathrm{H}_{26} \mathrm{O}_{2}$ & -13.71 & 1 & $81 \mathrm{GLU}$ & 2.027404 \\
\hline 15 & $\mathrm{C}_{40} \mathrm{H}_{56} \mathrm{O}_{2}$ & -14.78 & $*$ & $*$ & $*$ \\
\hline 18 & $\mathrm{C}_{40} \mathrm{H}_{58}$ & -16.05 & $*$ & $*$ & $*$ \\
\hline 19 & $\mathrm{C}_{30} \mathrm{H}_{48} \mathrm{O}_{3}$ & -14.65 & 1 & $145 \mathrm{ASP}$ & 2.654306 \\
\hline 25 & $\mathrm{C}_{40} \mathrm{H}_{56} \mathrm{O}_{2}$ & -16.62 & $*$ & $*$ & $*$ \\
\hline
\end{tabular}

Table 4: Binding Energy Values Of Cannabino, Lutein, Neurosporene, Oleanoic Acid, Ziaxenthin Compounds Complex with CDK2 (Pdb Ref.: 2BHH) Enzyme.

of 25 studied molecules, 5 molecules showing better interactions are selected for further analysis. The selected molecules are Cannabinol (Molecule No. 7), Lutein (Molecule No. 15), Neurosporene (Molecule No. 18), Oleanolic Acid (Molecule No. 19) and Zeaxanthin (Molecule No. 25). The binding energy values for the selected five molecules are ranging from $-13.71 \mathrm{kcal} . \mathrm{mol}^{-1}$ to $-16.62 \mathrm{kcal}^{\mathrm{mol}} \mathrm{m}^{-1}$. Table 4 shows the binding energy values and possible $\mathrm{HB}$ whereas, Table 5 shows the docking images in Wire-frame and CPK modes for best five selected compounds.

To understand the stability of ligand-protein complex and possibilities of various conformations of ligand in active site, cluster studies for best five molecules were performed.

\section{Cluster analysis}

The cluster analysis helps in understanding the conformation of ligand molecules in docking site at the time of flexible interactions. Higher the cluster number along with higher binding energy shows the possibilities of best fitting of ligand and hence higher ligand-protein complex stability. Autodock provides number of cluster values along with possible binding energies. Top rank three such values along with corresponding binding energies were analyzed and reported in Table 6. In this set of molecules the highest number of cluster 31 is reported for Oleanolic acid (molecule number 19) having binding energy $-14.66 \mathrm{kcal} . \mathrm{mol}^{-1}$.

\section{Conclusion}

The molecular docking studies of twenty five Terpene based natural compounds report negative binding energies and compact inhibition. A few among them also report the possibilities of hydrogen bonding. Cannabinol, Lutein, Neurosporene, Oleanolic acid and Zeaxanthin are reported as the best inhibitors as they show better ligand-enzyme interactions and stability. Therefore they show potency to be antiCDKs agents. Their reported binding energies ranging from $-13.0 \mathrm{kcal}$. $\mathrm{mol}^{-1}$ to $16.50 \mathrm{kcal}^{\mathrm{mol}}{ }^{-1}$ are reported in Table 7 .

Molecule no. 7 and 19 having smaller surface areas compared to molecule no. 15, 18 and 25. Molecule no. 7 and 19 bind in active site and remain within the boundary of selected active site, whereas, molecule no. 15, 18 and 25 are taking more space due to long chain compounds. This can be confirmed from the docking pictures displayed in Table 5. It is also reported that molecule having higher surface area and fits in active site of receptor enzyme gives better binding energy value compared to molecule having lower surface area. Molecule no. 7 and 19 shows better binding energy values due to the presence of 
Citation: Ganatra SH, Suchak AS (2012) Inhibition Studies of Naturally Occurring Terpene based Compounds with Cyclin-Dependent Kinase 2 Enzyme. J Comput Sci Syst Biol 5: 068-073. doi:10.4172/jcsb.1000092

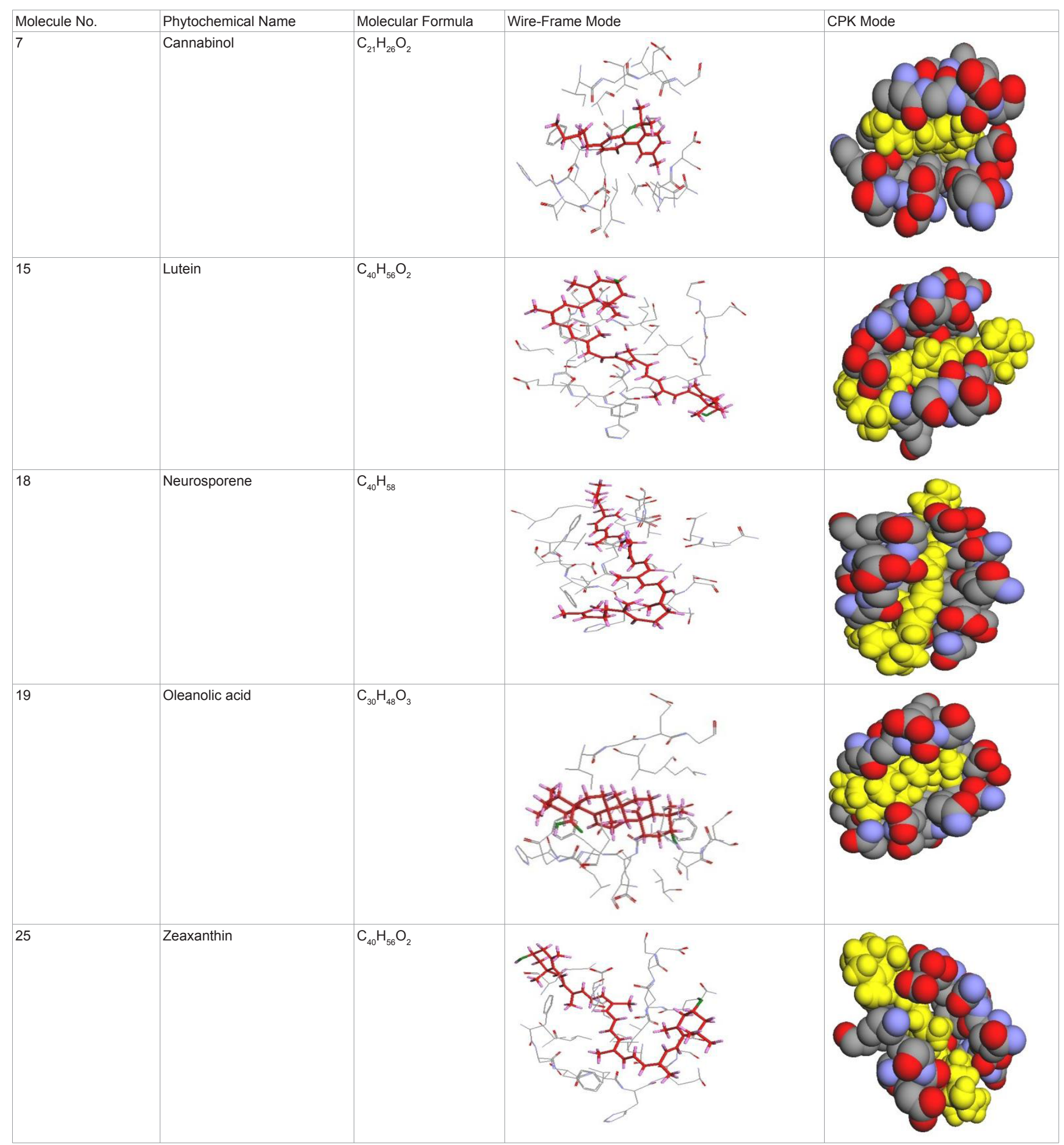

Table 5: The Interactions of Cannabino, Lutein, Neurosporene, Oleanoic Acid, Ziaxenthin Compounds with CDK2 (Pdb Ref. 2BHH) Enzyme.

one hydrogen bonding. Figures 1 and 2 show the docking pictures of Cannabinol and Oleanolic acid (Molecule Number 7 and 19) with receptor enzyme along with one hydrogen bond respectively.

81 Glutamine and 145 Aspartic acid of receptor enzyme are the most prone amino acids participating in making hydrogen bonds with the ligand atoms.
Cluster study represents number of possible conformations of ligand in active site of enzyme. Nearly all selected molecules show higher cluster size, except Neurosporene. Cannabinol and Oleanolic acid are two small molecules and show higher cluster size as per expectation. It also confirms the procedural correctness of docking work and validation of model. 
Citation: Ganatra SH, Suchak AS (2012) Inhibition Studies of Naturally Occurring Terpene based Compounds with Cyclin-Dependent Kinase 2 Enzyme. J Comput Sci Syst Biol 5: 068-073. doi:10.4172/jcsb.1000092

\begin{tabular}{|c|c|c|c|c|c|c|}
\hline \multirow{3}{*}{ Molecule Number } & \multicolumn{6}{|c|}{ Binding energy ( B. E ) $\Delta \mathrm{G}$ in $\mathrm{kcal} / \mathrm{mol} /$ Cluster Size } \\
\hline & \multicolumn{2}{|r|}{ 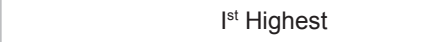 } & \multicolumn{2}{|r|}{ II $^{\text {nd }}$ Highest } & \multicolumn{2}{|r|}{ IIIrd Highest } \\
\hline & B. E. & Number of Conformations & B. E. & Number of Conformations & B. E. & Number of Conformations \\
\hline 7 & -13.71 & 27 & -10.93 & 3 & -10.10 & 2 \\
\hline 15 & -14.79 & 11 & -14.41 & 9 & -14.50 & 3 \\
\hline 18 & -16.05 & 7 & -13.90 & 2 & -13.52 & 2 \\
\hline 19 & -14.66 & 31 & -11.61 & 3 & -10.94 & 3 \\
\hline 25 & -16.62 & 21 & -8.56 & 4 & -9.14 & 3 \\
\hline
\end{tabular}

Table 6: Cluster (Number of Conformations) for Terpene Based Ligand Compounds with CDK2 (PDB Ref. 2BHH) Enzyme.

\begin{tabular}{|c|c|c|}
\hline Class of Compound & \multicolumn{2}{|c|}{ CDK2 (PDB Ref. : 2BHH) Enzyme } \\
\hline \multirow{2}{*}{ Terpene } & Minimum $\Delta \mathrm{G} \mathrm{kcal} \cdot \mathrm{mol}^{-1}$ & Maximum $\Delta \mathrm{G} \mathrm{Kcal} \cdot \mathrm{mol}^{-1}$ \\
\hline & -7.96 & -16.62 \\
\hline
\end{tabular}

Table 7: Minimum and Maximum Binding Energy ( $\triangle \mathrm{G}$ in Kcal.Mol-1) of Terpene-Based Compounds with CDK2 (PDB Reference 2BHH) Enzyme.

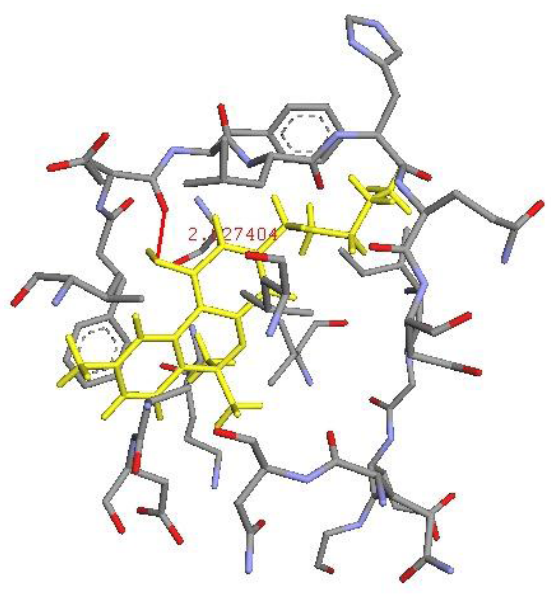

Figure 1: Docking picture of Cannabinol (Molecule Number 7) with CDK2 (PDB Reference $2 \mathrm{BHH}$ ) along with one hydrogen bond. (Bond distance $2.42 \AA$ ).

\section{References}

1. Zimmerman M (2000) Phytochemicals: Nutrients whose time has come. Nutrition Science News.

2. Duke J (1992) Handbook of biologically active phytochemicals and their activities. CRC Press, Florida.

3. Tang W, Eisenbrand G (1992) Chinese drugs of plant origin. Springer Publications, Verlag.

4. Koehn FE, Carter GT (2005) The evolving role of natural products in drug discovery. Nat Rev Drug Discov 4: 206-220.

5. Newman DJ, Cragg GM, Snader KM (2000) The influence of natural products upon drug discovery. Nat Prod Rep 17: 215-234.

6. Johnson IS, Armstrong JG, Gorman M, Burnett JP Jr. (1963) The vinca alkaloids: a new class of oncolytic agents. Cancer Res 23: 1390-1427.

7. Paduch R, Kandefer-Szerszeń M, Trytek M, Fiedurek J (2007) Terpenes: substances useful in human healthcare. Arch Immunol Ther Exp (Warsz) 55: 315-327.

8. Williams SD, Birch R, Einhorn LH, Irwin L, Greco FA, et al. (1987) Treatment of disseminated germ-cell tumors with cisplatin, bleomycin, and either vinblastine or etoposide. N Engl J Med 316: 1435-1440.

9. Wani MC, Taylor HL, Wall ME, Coggon P, McPhail AT (1971) Plant antitumor agents. VI. The isolation and structure of taxol, a novel antileukemic and antitumor agent from Taxus brevifolia. J Am Chem Soc 93:2325-2327.

10. Norbury C, Nurse P (1992) Animal cell cycles and their control. Annu Rev Biochem 61: 441-470.

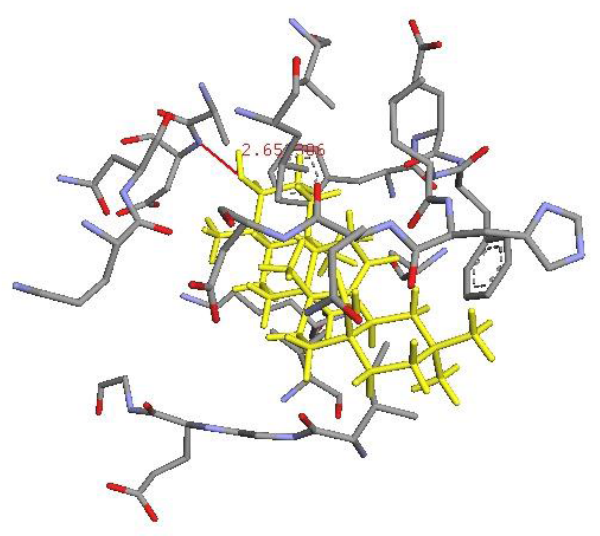

Figure 2: Docking picture of Oleanolic acid (Molecule Number 19) with CDK2 (PDB Reference 2BHH) along with one hydrogen bond. (Bond Distance $2.65 \AA$ ).

11. Loyer P, Trembley JH, Katona R, Kidd VJ, Lahti JM (2005) Role of CDK/cyclin complexes in transcription and RNA splicing. Cell Signal 17: 1033-1051.

12. Horiuchi D, Huskey NE, Kusdra L, Wohlbold L, Merrick KA, et al. (2012) Chemical-genetic analysis of cyclin dependent kinase 2 function reveals an important role in cellular transformation by multiple oncogenic pathways. Proc Natl Acad Sci U S A 109: E1091-E1027.

13. Desai D, Gu Y, Morgan DO (1992) Activation of human cyclin-dependent kinases in vitro. Mol Biol Cell 3: 571-582.

14. Gu Y, Rosenblatt J, Morgan DO (1992) Cell cycle regulation of CDK2 activity by phosphorylation of Thr160 and Tyr15. EMBO J 11: 3995-4005.

15. Ikuta M, Kamata K, Fukasawa K, Honma T, Machida T, et.al. (2001) Crystallographic approach to identification of cyclin-dependent kinase 4 (CDK4)-specific inhibitors by using CDK4 mimic CDK2 protein. J Biol Chem 276: $27548-27554$.

16. Cambridge Corporations. Chemdraw Software, Cambridge M.A. 02140 USA.

17. Rose PW, Beran B, Bi C, Bluhm WF, Dimitropoulos D, et al. (2011) The RCSB Protein Data Bank: redesigned web site and web services. Nucleic Acids Res 39: D392-D401.

18. Morris GM, Goodsell DS, Halliday RS, Huey R, Hart WE, et al. (1998) Automated docking using a lamarckian genetic algorithm and an empirical binding free energy function. J Comput Chem 19: 1639-1662.

19. Stoddard BL, Koshland DE Jr. (1993) Molecular recognition analyzed by docking simulations: The aspartate receptor and isocitrate dehydrogenase from Escherichia coli. Proc Natl Acad Sci U S A 90: 1146-1153.

20. Jeffery CJ, Koshland DE Jr. (1993) Three-dimensional structural model of the serine receptor ligand- binding domain. Protein Sci 2: 559-566. 
Citation: Ganatra SH, Suchak AS (2012) Inhibition Studies of Naturally Occurring Terpene based Compounds with Cyclin-Dependent Kinase 2 Enzyme. J Comput Sci Syst Biol 5: 068-073. doi:10.4172/jcsb.1000092

21. Goodsell DS, Lauble H, Stout CD, Olson AJ (1993) Automated Docking in Crystallography: Analysis of the Substrates of Aconitase. Proteins 17: 1-10.

22. Stoddard BL, Koshland DE Jr. (1992) Prediction of the structure of a receptor protein complex using a binary docking method. Nature 358: 774-776.

23. Mahmoudian M (1997) The cannabinoid receptor: Computer-aided molecular modeling and docking of ligand. J Mol Graph Model 15: 149-153.

24. Lorber DM (1999) Computational drug design. Chemistry and Biology 6: R227-R228.

25. Rao MS, Olson AJ (1999) Modelling of factor Xa-inhibitor complexes: a computational flexible docking approach. Proteins 34: 173-83.

26. Warren GL, Andrews CW, Capelli AM, Clarke B, LaLonde J, et al. (2006) A critical assessment of docking programs and scoring functions. J Med Chem 49: 5912-5931.

27. Perola E, Walters WP, Charifson PS (2004) A Detailed Comparison of Curren Docking and Scoring Methods on Systems of Pharmaceutical Relevance. Proteins 56: 235-249.
28. Muegge I, Martin YC (1999) A general and fast scoring function for proteinligand interactions: a simplified potential approach. J Med Chem 42: 791-804.

29. Terp GE, Johansen BN, Christensen IT, Jørgensen FS (2001) A new concept for multidimensional selection of ligand conformations (MultiSelect) and multidimensional scoring (MultiScore) of protein-ligand binding affinities. J Med Chem 44: 2333-2343.

30. Diller DJ, Merz KM Jr. (2001) High throughput docking for library design and library prioritization. Proteins 43: 113-124.

31. Lamb ML, Burdick KW, Toba S, Young MM, Skillman AG, et al. (2001) Design, docking, and evaluation of multiple libraries against multiple targets. Proteins 42: 296-318.

32. Goodsell DS, Olson AJ (1990) Automated docking of substrates to proteins by simulated by annealing. Proteins 8: 195-202.

33. Deng Z, Chuaqui C, Singh J (2004) Structural interaction fingerprint (SIFt) a novel method for analyzing three-dimensional protein-ligand binding interactions. J Med Chem 47: 337-344. 